\title{
Menakar Kekuatan Politik Australia - Jepang: Studi Kerjasama Bilateral Bidang Ekonomi dan Pertahanan
}

\section{Measuring the Political Power of Australia - Japan: Study of Bilateral Cooperation in the Economy and Defense}

\author{
Amanda Nabilla Nuryadin \\ Universitas Islam Negeri Syarif Hidayatullah Jakarta \\ Jl. Ir H. Juanda No.95, Kota Tangerang Selatan, Indonesia \\ *corresponding author E-mail: amandanuryaddin09@gmail.com
}

Diterima: 19 April 2020; Direvisi: 19 Juli 2020; Disetujui: 22 Juli 2020

\begin{abstract}
ABSTRAK
Hubungan bilateral antara Australia dan Jepang dari waktu ke waktu menunjukkan hasil yang positif dimana hubungan tersebut semakin erat dengan dilakukannya kerjasama. Penelitian ini bertujuan untuk melihat hubungan bilateral di antara kedua negara yang dapat menguatkan hubungan politik dan diplomasi antar kedua negara. Pada penelitian ini, berfokus kepada berbagai kerjasama apa yang dilakukan Australia dan Jepang untuk melihat seberapa kuat hubungan politik yang dijalin kedua negara tersebut, serta dampak apa yang dihasilkan atas adanya hubungan bilateral tersebut. Pemilihan topik ini didasarkan atas keingin tahuan penulis tentang kekuatan politik antar dua negara dan hubungan bilateral kedua negara tersebut yang makin hari semakin erat karena adanya fenomena "kebangkitan China". Metode yang digunakan berupa penelitian Kualitatif dengan menggunakan studi literature dalam pengumpulan data. Penelitian ini menunjukkan bahwa Australia dan Jepang menikmati salah satu kemitraan ekonomi paling signifikan di kawasan Asia Timur. Berdasarkan dari beberapa bidang kerjasama yang dilakukan oleh kedua negara tersebut, maka antara Australia dan Jepang tidak dapat dipisahkan dalam menjalin kerjasama dan perekatan hubungan timbal balik yang saling menguntungkan. Dan, berdampak pada hubungan politik dan diplomasi di antara kedua negara semakin kuat. Hal tersebut telah tercermin dalam realitas hubungan kedua negara berdasarkan pertimbangan nasional masing-masing.
\end{abstract}

Kata kunci: Australia, Hubungan Bilateral, Jepang, Kerjasama

\begin{abstract}
Bilateral relations between Australia and Japan from time to time show positive results where the relationship is increasingly tight with the cooperation. This study aims to look at bilateral relations between the two countries which can strengthen political relations and diplomacy between the two countries. In this research, we focus on various collaborations between Australia and Japan to see how strong the political relations are established between the two countries, and
\end{abstract}


what impact this bilateral relationship will have. The choice of this topic is based on the writer's curiosity about the political power between the two countries and the bilateral relations between the two countries which are getting closer and closer due to the phenomenon of "the rise of China". The method used in the form of qualitative research using literature studies in data collection. This research shows that Australia and Japan enjoy one of the most significant economic partnerships in the East Asian region. Based on several fields of cooperation between the two countries, Australia and Japan cannot be separated in establishing cooperation and gluing mutually beneficial relations. And, the impact on political relations and diplomacy between the two countries is getting stronger. This has been reflected in the reality of relations between the two countries based on their respective national considerations.

Keywords: Australia, Bilateral Relations, Cooperation, Japan

\section{PENDAHULUAN}

Hubungan internasional dapat didefinisikan sebagai kegiatan politik dan jenis serta aspek interaksi lainnya antara dua atau lebih negara. Bidang akademik hubungan internasional adalah cabang ilmu politik yang berkaitan dengan studi hubungan antar negara, kebijakan luar negeri negara-bangsa, dan mekanisme dan institusi, seperti organisasi internasional, organisasi antar pemerintah, internasional dan nasional, organisasi non pemerintah dan perusahaan multinasional di mana negara berinteraksi (Devetak, George, \& Percy, 2017). Karena negara memiliki sifat yang tidak jauh seperti manusia, yaitu makhluk sosial dan membutuhkan bantuan dari makhluk lainnya, maka dapat diartikan bahwa negara juga membutuhkan negara lain untuk memenuhi kebutuhan dan kepentingan nasionalnya masing-masing.

Suatu negara itu tidak mungkin bisa menghidupi warga negara nya tanpa adanya campur tangan dengan negara lain. Salah satu cara untuk memenuhi kebutuhan dan kepentingannya adalah dengan kerjasama dan diplomasi. Pada umumnya kerjasama internasional meliputi beberapa bidang yaitu kerjasama dibidang ekonomi, pendidikan, teknologi, pertahanan, serta pertahanan. Selain akan mempererat hubungan, dan memperkuat rasa persahabatan melalui diplomasi yang baik dari negara yang menjalani dan mengikuti kerjasama, ini juga akan berdampak terhadap untungnya negara masing-masing yang mengikuti kerjasama, juga dapat memacu laju 
pertumbuhan ekonomi setiap negara dan dapat menciptakan keadilan dan kesejahteraan yang merata bagi seluruh warga negara masing-masing.

Australia dan Jepang memiliki ikatan kerjasama yang sangat kuat serta bersama-sama mengembangkan demokrasi di kawasan Asia-Pasifik. Hubungan erat mereka terjadi karena adanya kedekatan satu sama lain dengan negara Amerika Serikat. Sejak negara China menjadi negara yang mempunyai pengaruh terbesar di Asia, Jepang semakin mempererat hubungannya dengan Australia. Hubungan bilateral antara Australia dengan Jepang secara luas dianggap sebagai prioritas kebijakan luar negerinya selama 1980 sampai 1990-an. Australia juga secara aktif terlibat dalam diplomasi dalam bidang ekonomi regional. Kerjasama ekonomi regional merupakan kepentingan nasional yang signifikan bagi kedua negara, dan keduanya didorong untuk bekerjasama dalam membangun institusi baru di wilayah tersebut.

Meskipun kepentingan kedua negara dalam mempromosikan kerjasama ekonomi regional berbeda, unsur-unsur tertentu menyatukan kedua negara dalam upaya pembangunan kelembagaan ini. Elemen yang paling mencolok adalah saling melengkapi diplomatik antara kedua negara. Upaya Jepang untuk menaklukkan wilayah Asia Pasifik dalam Perang Dunia II dan kehadiran ekonominya yang berkembang pesat merupakan hambatan bagi keterlibatannya dalam diplomasi ekonomi regional. Kemitraan dengan Jepang berfungsi dengan sukses sebagai bagian dari strategi Australia melalui inisiatif bersama mereka dalam membangun lembaga ekonomi regional seperti Dewan Kerjasama Ekonomi Pasifik (PECC) pada tahun 1980 dan forum Kerjasama Ekonomi Asia Pasifik (APEC) pada tahun 1989, masing-masing berfungsi sebagai katalisator dalam mempromosikan keterlibatan regional Australia pada waktu itu. Lembaga-lembaga regional ini dirancang untuk mempromosikan kerja sama ekonomi dengan negara-negara anggota dan, lebih simbolis, untuk memelihara kebersamaan dengan mereka dengan mengatasi masalah bersama dan mengejar tujuan bersama seperti liberalisasi 
perdagangan di wilayah tersebut (Seran, 2014).

Penelitian yang telah dilakukan oleh Elisabeth (2016) mengenai dinamika hubungan Australia dan Asia Timur menghasilkan bahwa Australia mempunyai peranan penting dalam menjaga pertahanan energi di masa depan di wilayah Asia Timur. Wijayanti (2019) mengenai dinamika hubungan Australia dan Indonesia yang menghasilkan faktor penyebab pasang naik dan surutnya hubungan Indonesia-Australia adalah perbedaan dalam hal pelaksanaan demokrasi dan budaya politik, dan kebijakan politik luar negeri. Serta penelitian oleh Rahayu \& Arianti (2014) keputusan Australia melarang ekspor uranium membuat beberapa negara mengubah dinamika geopolitik. Terkait itu, Malcolm Cook dan Thomas Wilkins (2011) membahas tentang perubahan politik Australia dan Jepang selama tiga tahun terakhir telah memberikan ujian yang sangat baik terhadap hubungan pertahanan yang berkembang pada saat ini.

Sebuah ujian yang telah dilewati dengan mudah meskipun ada kekhawatiran di awal. Pencapaian yang tenang, tampaknya akan terus berlanjut di masa yang akan mendatang karena empat faktor yang saling terkait. Yaitu, pertama, Australia dan Jepang sekarang memiliki banyak peluang untuk kerjasama operasional yang lebih dekat untuk berbagai kemungkinan yang sangat beragam. Kedua, keprihatinan strategis timbal balik yang telah memotivasi pencapaian tenang ini semakin meningkat, bukan memoderasi. Ketiga, kebijakan pertahanan Amerika Serikat semakin bergantung dan menuntut dukungan dari sekutu regionalnya. Keempat, Australia dan Jepang berkomitmen untuk meningkatkan kemampuan proyeksi kekuatan mereka dengan cara yang sama (WILKINS, 2020).

Kesamaan yang dimiliki oleh artikel penelitian yang ditulis oleh Malcolm Cook dan Thomas Wilkins dengan Artikel tersebut adalah memiliki persamaan yang sama mengenai sejarah awal adanya hubungan bilateral Australia dan Jepang. Sedangkan perbedaan yang terdapat dalam keduanya, ialah jurnal penelitian yang ditulis oleh Malcolm dan Tomas lebih kepada membahas kerjasama di bidang pertahanan saja. Sedangkan penelitian ini juga memfokuskan pada kerjasama dalam bidang ekonomi yang berdampak pada 
hubungan politik/diploma. Pada artikel ini penulis melihat perspektif berbeda dari ketiga penelitian terdahulu, yaitu melihat kekuatan hubungan politik antara Australia dan Jepang yang mana dilihat dari hubungan kerjasama yang telah mereka lakukan selama ini.

Pada tahun 2007 hingga 2014, Australia dan Jepang telah membina sebuah komitmen menuju hubungan kerjasama pertahanan atau pertahanan pada level tinggi. Australia dan Jepang dalam hal ini melakukan kerjasama dan mengadakan pertemuan dalam rangka membahas penguatan kerjasama pertahanan dan pertahanan secara bilateral. Namun, tidak dapat dipungkiri bahwa di balik itu semua Australia dan Jepang merupakan negara yang saling beraliansi untuk mencapai tujuan bersama dan mewujudkan pengertian antara bangsa dalam membina dan menegakkan perdamaian di dunia. Tujuan utama dalam penelitian ini adalah melihat kekuatan politik di antara kedua negara melalui hubungan bilateral yang dilakukan kedua belah pihak.

\section{METODE PENELITIAN}

Metode penelitian yang digunakan dalam membuat artikel ini adalah metode kualitatif. Metode kualitatif yaitu penelitian yang dilakukan dengan cara mengumpulkan data yang mana berhubungan dengan tema dari artikel ini, yaitu menakar kekuatan politik studi pada Hubungan Bilateral Australia Jepang dalam Kerja Sama Bidang Ekonomi dan Pertahanan (Yusuf, 2016).

Metode penelitian kualitatif ini secara general memiliki dua tujuan, yaitu untuk menggambarkan dan mengungkap serta menggambarkan dan menjelaskan. Metode ini juga biasanya digunakan untuk menjawab pertanyan mengenai 'apa, bagaimana dan mengapa' dari adanya sebuah fenomena daripada mempertanyakan 'berapa banyak'. Selain itu, metode kualitatif juga dapat digunakan untuk memahami bagaimana suatu individu maupun kelompok yang ada melihat isu tertentu. Menurut Cresswell (2016), Karakteristik dari penelitian kualitatif, yaitu memiliki banyak sumber data, sumber data tersebut bisa berupa dari data sekunder maupun primer yang didapatkan dari dokumen - dokumen yang berasal dari pemerintahan Jepang 
dan Australia yang dipublikasihkan pada laman resmi pemerintahan. Data sekunder, yaitu data-data yang diperoleh dari berbagai macam literatur seperti jurnal, buku, artikel, internet dan juga laporan sehingga akan mampu menjawab pertanyaan penelitian.

Penulis kemudian menuliskan penelitian ini dengan metode penulisan deduktif, yang mana merupakan sebuah metode yang memulai pembahasannya dengan pembahasan teoritis sebagai sebuah gambaran yang general lalu kemudian diakhiri dengan adanya kesimpulan yang merupakan hasil penyatuan data yang telah terkumpul dengan pertanyaan penelitian yang ada. Selanjutnya, dengan metode historis analisis, yaitu suatu metode penelitian yang menghasilkan suatu metode pemecahannya yang ilmiah dan dari perspektif historis suatu masalah, yakni dengan cara pemecahan suatu masalah melalui pengumpulan data dan fakta-fakta khusus tentang kejadian masa lampau dalam hubungannya dengan masa kini sebagai sebuah rangkaian yang tidak terputus dan saling berhubungan satu sama lain (Nugrahani \& Al-Ma'ruf, 2015).

\section{TEMUAN DAN PEMBAHASAN}

\section{Australia dan Jepang}

Australia dan Jepang memiliki banyak kesamaan. Terletak di garis bujur yang serupa, keduanya adalah negara kepulauan yang konsekuensinya memiliki minat yang kuat dalam urusan maritim (Chapman, 2016). Kedua negara adalah mitra dagang utama. Keduanya menanggapi dinamika kekuatan yang berubah di kawasan Asia-Pasifik, khususnya kebangkitan Cina, dari perspektif menjadi sekutu dekat Amerika Serikat, meskipun Jepang secara geografis jauh lebih dekat dengan Cina daripada Australia. Keduanya adalah negara demokrasi yang memiliki komitmen kuat terhadap supremasi hukum di dalam negeri dan pada tatanan berbasis peraturan secara internasional. Prioritas umum dari kedaulatan hukum internasional lebih dari sekadar citacita abstrak ini mengikuti dari keyakinan bahwa supremasi hukum merupakan prasyarat penting untuk kemakmuran dan pertahanan 
berkelanjutan (Lang \& Scott, 2014). Australia memiliki banyak tujuan di kawasan Asia, dan membutuhkan lebih dari satu rencana untuk memaksimalkan kepentingan strategisnya di sana. Untuk memaksimalkan kepentingannya, Australia menjalankan kerjasama dengan negara di Asia. Salah satunya ialah Jepang. Australia dan Jepang menikmati salah satu kemitraan ekonomi paling signifikan di kawasan Asia Timur. Hubungan ekonomi Australia dan Jepang telah berkembang atas dasar kepentingan pelengkap yang kuat dan kerja sama dalam berbagai bidang.

\section{Kerjasama dalam Bidang Ekonomi}

Kekuatan dan batas yang meluas dari hubungan Australia-Jepang dalam bidang ekonomi setelah penandatanganan Perjanjian Perdagangan pada tahun 1957, perjanjian tersebut merupakan bukti kekuatan komplementaritas fundamental dan berkelanjutan. Untuk Australia, yang selalu mencari modal tambahan, investasi Jepang memiliki semua karakteristik terbaik yaitu telaten, cakrawala jangka panjang, teknologi dan keterampilan, jaringan global dan diresapi dengan hubungan kepercayaan.

Sifat saling melengkapi pertama, yang masih berlaku adalah ketergantungan Jepang pada energi dan sumber daya yang diimpor untuk mendorong pertumbuhan ekonominya dan berlimpahnya pasokan dan sumber daya berkualitas tinggi yang andal dari Australia. Bukan kebetulan bahwa untuk jangka waktu yang lama, Jepang adalah pembeli tunggal utama ekspor utama Australia pada barang seperti wol, batu bara, bijih besi, gas alam cair (LNG) dan pariwisata.

Kontrak jangka panjang dan investasi modal dari Jepang menciptakan fondasi seluruh industri di Australia (bijih besi, batubara, LNG) yang sekarang memasok banyak negara lain. Australia adalah pemasok utama produkproduk utama ke Jepang, termasuk komoditas pertanian, mineral, dan sumber daya energi. Pada tahun 1990, ekspor ini menyumbang 85 persen dari total ekspor barang dagangan Australia pada 2004, mereka menyumbang 89 persen ekspor Australia ke Jepang, sebagian karena meningkatnya ekspor LNG. Pada 
tahun 1989, Australia mengekspor wol senilai \$ AS804 juta ke Jepang, pada tahun itu wol adalah ekspor terbesar kelima Australia. Dalam produk primer, komposisi ekspor Australia ke Jepang telah berubah sedikit sejak 1990, dengan ekspor pedesaan menurun (terutama karena menurunnya ekspor wol ke Jepang), sementara ekspor makanan dan lainnya memperluas bagian mereka (Yadav, 2015).

Walaupun perdagangan jasa antara Australia dan Jepang dalam skala yang lebih kecil dari perdagangan barang, namun itu merupakan komponen penting dari perdagangan bilateral. Jepang adalah pasar terbesar ketiga Australia untuk ekspor jasa, sementara itu merupakan sumber impor jasa terbesar keempatnya. Australia adalah pasar terbesar kedua belas Jepang untuk ekspor jasa dan sumber kedelapan terbesar dari impor jasa. Kwitansi perjalanan, termasuk pariwisata Jepang di Australia, merupakan bagian terbesar dari perdagangan jasa. Kemampuan dan aset Australia dan Jepang di berbagai sektor, seperti makanan dan minuman, energi terbarukan, ilmu kehidupan dan layanan keuangan, juga saling melengkapi.

Ada kolaborasi yang berkembang dalam inovasi antara Australia dan Jepang di berbagai bidang: kedokteran regeneratif, peralatan medis, akuakultur, agtech dan foodtech, digitech, fintech, teknologi satelit, serat karbon, kecerdasan buatan, Internet dan pencetakan 3D (Panagiotopoulos, 2016). Pada 2004, ekspor Australia turun menjadi US \$ 35 juta dan wol merupakan ekspor ke 33 Australia. Perubahan ini mencerminkan dua faktor: semakin pentingnya Cina sebagai pusat pemrosesan wol dan penurunan jumlah ternak Australia sejak akhir 1980-an.

Telah ada pertumbuhan kuat dalam komoditas sumber daya utama seperti batu bara, bijih besi, aluminium, bijih tembaga, gas minyak bumi, dan minyak mentah. Beberapa ekspor pertanian juga menunjukkan pertumbuhan yang stabil, terutama keju, lobak (atau dikenal sebagai kanola) dan pakan ternak.

Ekspor kehutanan seperti serpihan kayu juga telah tumbuh secara 
progresif. Jepang membeli 43 persen dari total ekspor batubara Australia, 37 persen dari total ekspor bijih besi. Pada tingkat produk ekspor selain bijih besi, batubara, LNG Australia sangat terkonsentrasi pada daging sapi - yang secara bersama-sama menyumbang beberapa persen dari total ekspor Australia ke barang dagangan Jepang. Jepang adalah pasar terbesar untuk batubara, aluminium dan daging sapi dan terbesar kedua untuk bijih besi. Jepang membeli 49 persen dari ekspor daging sapi. Ekspor daging sapi ke Jepang pada tahun 2004 jauh lebih tinggi karena ditemukannya bovine spongiform encephalopathy (BSE) atau di dalam dunia medis yang dikenal sebagai penyakit sapi gila di Amerika Serikat pada akhir tahun 2003 dan Jepang selanjutnya melarang impor daging sapi dari negara itu.

Jepang telah lama menjadi pasar ekspor terpenting Australia. Total ekspor Australia ke Jepang menyumbang 3 persen dari PDB Australia pada tahun 2004 (Cassidy \& Kosev, 2015). Australia adalah salah satu sumber impor terbesar Jepang secara keseluruhan dan sumber utama sejumlah komoditas yang sangat diperlukan. Selama beberapa dekade, Australia telah menjadi sumber bahan baku yang stabil dan aman untuk Jepang, menguntungkan kedua negara. Pada gilirannya, Jepang memberi Australia sejumlah besar produk manufaktur yang memberikan kontribusi signifikan bagi kesejahteraan konsumen dan efisiensi industrinya.

Aliran investasi juga penting. Jepang adalah sumber investasi asing terbesar ketiga di Australia dan ada kapasitas yang ditunjukkan untuk memperluas investasi Australia di Jepang. Perdagangan jasa sangat kuat di beberapa daerah seperti pariwisata, tetapi tetap proporsi kecil dari total perdagangan bilateral. Komite Kerjasama Bisnis Australia Jepang dan mitranya JABCC, keduanya didirikan pada tahun 1962, telah berkontribusi dalam membangun hubungan yang kuat antara bisnis Australia dan Jepang, serta membantu mengembangkan hubungan yang saling menguntungkan dengan pemerintah masing-masing. Hubungan perdagangan bilateral antara Jepang dan Australia berbeda dari hubungan antara banyak negara maju 
lainnya. Ini mencerminkan saling melengkapi keunggulan alami kedua negara: Australia adalah negara yang kompetitif, efisien, kaya sumber daya, sementara Jepang terkenal dengan kemampuannya untuk menghasilkan barang dan jasa berteknologi tinggi yang kompetitif.

Kerjasama ekonomi atau perjanjian kemitraan ekonomi antara Australia-Jepang lainnya ialah JAEPA (Japan - Australia Economic Partnership Agreement) yang mulai berlaku pada 15 Januari 2015. Perjanjian Kemitraan Ekonomi Jepang-Australia (JAEPA) memberikan manfaat besar bagi perekonomian Australia, membuatnya lebih mudah untuk melakukan bisnis dengan Jepang, mitra dagang terbesar kedua. Perjanjian ini akan memperkuat dan memperdalam perdagangan antara dua ekonomi terbesar di Asia-Pasifik. JAEPA adalah perjanjian perdagangan bilateral paling liberal yang pernah disimpulkan Jepang, memberikan eksportir, importir, investor dan produsen Australia keuntungan yang signifikan atas pesaing internasional mereka. Ini akan memberikan akses pasar yang belum pernah terjadi sebelumnya dan keunggulan kompetitif untuk ekspor pertanian Australia - banyak di antaranya berbasis di Queensland.

Perjanjian inovatif ini akan secara signifikan meningkatkan akses ke ekonomi terbesar ketiga di dunia untuk bisnis Australia. JAEPA telah membantu menghasilkan minat baru dan ekspor penjualan untuk berbagai produk. Industri kenari Australia yang sedang berkembang adalah satu sektor yang akan diuntungkan dari penurunan tarif berdasarkan JAEPA. Jepang adalah importir biji kenari terbesar kedua di dunia, dan pemasok kenari Australia melaporkan peningkatan minat sekarang karena posisi kompetitif Australia telah membaik. Ekspor almond ke Jepang tumbuh dari 32 ton pada tahun 2014 menjadi 389 ton pada tahun 2015. Peningkatan volume ekspor dua belas kali lipat ini dapat dikaitkan dengan berbagai alasan termasuk tingkat eliminasi, peningkatan permintaan domestik dan faktor pasokan internasional. Walaupun ada beberapa pesaing di pasar ini, Australia dianggap sebagai pemasok yang diinginkan karena pertahanan pangan dan kedekatan 
geografisnya dengan Asia. Waktunya sangat ideal bagi para eksportir kacangkacangan dan buah-buahan kering Australia untuk mengambil keuntungan dari reputasi Australia dan momentum yang diperoleh dari JAEPA (Katagiri et al., 2015).

Pada Oktober 2018, Menteri Luar Negeri dan Menteri Pertahanan Jepang bertemu dengan Menteri Luar Negeri dan Menteri Pertahanan Australia di Sydney untuk menguatkan hubungan bilateralnya. Bersama Amerika Serikat, Australia dan Jepang berusaha membentuk kelompok segitiga untuk memperkuat kerja sama ekonomi dan meningkatkan investasi di dua kawasan yaitu Samudra Hindia dan Asia Pasifik demi melawan perkembangan ekonomi dan pengaruh China di kawasan.

\section{Kerjasama dalam Bidang Pertahanan}

Kerjasama dan pertukaran pertahanan Jepang - Australia telah berkembang sejak kedua negara mengumumkan Deklarasi Bersama tentang Kerja Sama Pertahanan pada Maret 2007. Hal ini ditunjukkan dengan diadakannya pertemuan puncak bilateral, konsultasi menteri luar negeri dan menteri pertahanan, atau "dua plus-dua "pertemuan, serta kesimpulan dan ratifikasi Perjanjian Akuisisi dan Lintas-Layanan (ACSA) dan Perjanjian Pertahanan Informasi (ISA). Latihan dan pelatihan bersama telah intensif, tidak hanya secara bilateral tetapi juga dalam pengaturan trilateral dengan sekutu bersama kedua negara, Amerika Serikat. Pada bulan September 2012, Jepang dan Australia mengadakan Konsultasi Menteri Luar Negeri dan Pertahanan keempat mengungkap dokumen kunci baru yang disebut "Visi dan Tujuan Bersama".

Dengan mendukung dokumen ini, Jepang dan Australia sepakat untuk mengukir bidang kerja sama baru sambil terus mengejar dan memperkuat kerja sama mereka di bidang yang ada dengan cara yang lebih efektif. Pemerintah Jepang dan Australia sangat menghargai kerja sama pertahanan bilateral mereka. Ketika Menteri Pertahanan Stephen Smith mengunjungi Jepang pada bulan September 2012, ia menyampaikan pidato di Institut Nasional untuk Studi Pertahanan (NIDS), menggambarkan Jepang sebagai "teman terdekat Australia dan pendukung terkuat 
(Australia) di Asia" dan memberikan pujian yang tinggi untuk pendalaman hubungan bilateral. Demikian juga, semakin beratnya Jepang yang melekat pada hubungan pertahanan Australia Australia ditunjukkan dalam buku putih tahunan Pertahanan Jepang.

Sejak versi 2010-nya, Australia berada di urutan teratas dalam daftar negara-negara mitra di mana Jepang berusaha untuk memperkuat hubungan bilateral. Salah satu alasan mengapa kedua pemerintah menghargai kerja sama pertahanan bilateral terletak pada rekam jejak mereka dalam kerja sama praktis. Sejak akhir Perang Dingin, otoritas pertahanan Jepang dan Australia telah melakukan kerja sama praktis di bidang kerja sama perdamaian internasional, termasuk PeaceKeeping Operation atau yang disingkat PKO di Kamboja pada 1992, PKO di Timor-Leste pada 2000, bantuan kemanusiaan dan bantuan bencana setelah gempa bumi Samudra Hindia pada Desember 2004, dan kerja sama untuk bantuan rekonstruksi kemanusiaan di Irak selama 2005-2006. Contoh yang lebih baru dari kerja sama bantuan kemanusiaan atau bantuan bencana Gempa Besar Jepang Timur pada Maret 2011.

Australia akhirnya mengirim ke Jepang ketiga pesawat pengangkut C-17 operasionalnya dan mengangkut unit pencarian dan penyelamatan, pasokan bantuan kemanusiaan, air yang dapat dikendalikan dari jarak jauh pompa, dan bahkan unit dari Brigade Kelima Belas SDF Jepang (JGSDF). Operasi Australia adalah kegiatan bantuan bencana paling substansial kedua yang dilakukan oleh pasukan asing setelah bencana itu (hanya yang kedua dari pasukan AS). Aktivitas kolaboratif yang sedang berlangsung lainnya adalah kerja sama bersama untuk PKO di Sudan Selatan. Pada Agustus 2012, pemerintah Jepang dan Australia mengumumkan bahwa personel dari Angkatan Pertahanan Australia (ADF) akan ditugaskan ke pusat koordinasi bantuan lokal yang dibentuk oleh Pasukan Bela Diri (SDF) di negara Afrika itu.

Menggeser Pusat Gravitasi menuju Wilayah Asia-Pasifik Kerja sama pertahanan yang dijalankan Jepang dan Australia sebagai "mitra strategis alami". Dalam beberapa tahun terakhir, kedua negara telah mulai semakin menggarisbawahi pentingnya wilayah ini. Australia telah membuat sejumlah 
dokumen kebijakan dalam dua tahun terakhir yang menetapkan kebijakan Australia untuk memperkuat keterlibatan di Asia-Pasifik dan lingkungan "Indo-Pasifik" yang lebih luas. Jepang dan Australia telah lama bekerja sama dalam berbagai aspek keterlibatan di kawasan Asia-Pasifik. Ke depan, tren yang muncul adalah bahwa organisasi pertahanan kedua negara memainkan peran yang semakin menonjol dalam pendekatan bersama Jepang-Australia terhadap kawasan tersebut. Salah satu alasan mengapa pengaturan dan latihan multilateral yang dipimpin oleh otoritas pertahanan dan militer mulai dikembangkan secara nyata. Hal ini berlaku untuk Pertemuan Menteri Pertahanan ASEAN-Plus (dikenal sebagai "ADMM-Plus"), yang didirikan pada tahun 2010. ADMM-Plus mengadakan pertemuan menteri kedua pada Agustus 2013 dan telah menetapkan dirinya sebagai menteri pertahanan pertama- memimpin mekanisme multilateral di kawasan Asia-Pasifik (Ishihara, 2014).

Sejak 2014, Perdana Menteri Abe dan Perdana Menteri saat itu Tony Abbott menggunakan frasa 'kemitraan strategis khusus' untuk menggambarkan hubungan antara negara mereka. Pada awal 2017, setelah provokasi Korea Utara, menteri pertahanan Jepang dan Australia mengadakan serangkaian pertemuan di mana mereka menyoroti nilai-nilai bersama dan oposisi mereka terhadap uji coba nuklir Korea Utara. Pada salah satu pertemuan itu, Menteri Luar Negeri Australia Julie Bishop menyatakan bahwa keduanya adalah "di antara negara-negara yang berpikiran sama di Indo-Pasifik". Pertemuan pada tahun 2018 antara Perdana Menteri Shinzo Abe dan Malcolm Turnbull meminta kedua pemimpin menegaskan kembali komitmen mereka untuk kerja sama pertahanan yang lebih baik, menekankan kembali nilai-nilai bersama mereka. Mereka selanjutnya mengumumkan negosiasi pakta militer baru yang akan memudahkan kedua negara untuk melakukan latihan kolaboratif. Perjanjian militer yang ditingkatkan, yang dikenal sebagai Reciprocal Access Agreement (RAA) (Barbantan, 2019).

\section{Analisis Kekuatan Politik Australia - Jepang di Asia}

Komunitas pertahanan Jepang sebagian besar menyambut kerjasama pertahanan yang lebih erat dengan Australia. Tetapi beberapa pakar, politisi, dan mantan pembuat kebijakan yang bermarkas di Australia telah menyatakan 
keprihatinan atas potensi risiko dan biaya yang terkait dengan pengejaran hubungan pertahanan yang lebih erat dengan Jepang di Australia - termasuk kemungkinan terjerat dalam konflik Tiongkok-Jepang di masa depan. Para kritikus berpendapat bahwa penyelarasan yang lebih dekat dengan Jepang bukan untuk kepentingan Australia, tidak hanya karena akan merusak hubungan Australia dengan China, tetapi juga karena hal itu dapat memecah Asia menjadi blok-blok bersenjata yang saling bermusuhan.

Pada akhirnya, ini bisa memaksa Australia untuk memilih antara Jepang dan Cina. Kekhawatiran ini, sampai batas tertentu, dapat dipahami, mengingat bahwa Jepang dikelilingi oleh lingkungan pertahanan yang semakin keras dan baru-baru ini memperluas kerjasama pertahanannya dengan mitra regional, seperti Australia dan India, dan meningkatkan aliansi yang ada dengan Amerika Serikat. Perkembangan ini telah membuat beberapa pengamat menyimpulkan bahwa Jepang sedang mengejar strategi penyeimbangan eksternal melawan China dengan berusaha memperkuat hubungannya dengan demokrasi yang berpikiran sama (Satake, 2015).

Hubungan kerjasama ini berdampak juga terhadap kegiatan politik di antara negara dengan semakin baiknya hubungan kerjasama di antara kedua negara mempengaruhi setiap kebijakan yang akan dilaksanakan negara tersebut dimana membawa kepada suatu kebijakan yang saling menguntungkan kedua negara, serta Australia dan Jepang, juga meningkatkan dalam hubungan-hubungan diplomatic semakin mudah dilaksanakan kedua negara dan bahkan menjadi negara yang sangat berpengaruh di kawasan asia.

\section{SIMPULAN}

Hubungan Australia-Jepang mempunyai sejarah yang panjang. Sejarah hubungan bilateral antara Australia dengan Jepang sudah terjalin sejak 1957 melalui Perjanjian Perdagangan. Hingga saat ini hubungan antara Australia Jepang terjalin sangat kuat dengan cara - cara diplomatik yang dijalankan oleh para pemimpin untuk mempererat hubungan bilateral antara keduanya. Adanya kerja sama bidang ekonomi dan pertahanan ini merupakan langkah yang sejalan dengan kepentingan yang dimiliki oleh Australia dan Jepang. 
Selama beberapa dekade ini, Australia telah menjadi sumber bahan baku yang stabil dan aman untuk Jepang, menguntungkan kedua negara.

Pada gilirannya, Jepang memberi Australia sejumlah besar produk manufaktur yang memberikan kontribusi signifikan bagi kesejahteraan konsumen dan efisiensi industrinya dalam bidang ekonomi. Terlebih lagi dengan adanya kebangkitan China, membuat Australia dan Jepang semakin memperkuat hubungan. Hubungan tersebut memperlihatkan hasil yang positif dimana kedua negara ini telah melakukan kerja sama praktis di bidang kerja sama perdamaian internasional, termasuk PeaceKeeping Operation. Namun, ditengah hubungannya yang semakin erat, ada pula hambatan yang dialami oleh kedua negara ini terlepas dari hambatan tersebut hubungan Australia dan Jepang membuat negara ini menjadi negara yang berpengaruh di kawasan asia.

\section{DAFTAR PUSTAKA}

Barbantan, A. (2019). Australia-Japan alliance: A blueprint for something bigger?

Cassidy, N., \& Kosev, M. (2015). Australia and the global LNG market. RBA Bulletin, March, 33-43.

Chapman, B. (2016). China's nine-dashed map: Continuing maritime source of geopolitical tension. Geopolitics, History, and International Relations, 8(1), 146-168.

Cook, M., \& Wilkins, T. S. (2011). Australia and Japan: allies in partnership. Asia Pacific Bulletin, (101), 17.

Cresswell, J. (2016). Research design: Pendekatan metode kualitatif, kuantitatif, dan campuran (Edisi 4). Yogyakarta: Pustaka Pelajar.

Devetak, R., George, J., \& Percy, S. (2017). An introduction to international relations. Cambridge University Press.

Elisabeth, A. (2016). Dinamika iiubungan Australia asia timur 19972005. Jurnal Penelitian Politik, 4(1).

Ishihara, Y. (2014). Japan-Australia Defence Cooperation in the Asia-Pacific Region. Beyond the Hub and Spokes: Australia-Japan Security Cooperation, 93-122. 
Katagiri, R., Asakura, K., Sasaki, S., Hirota, N., Notsu, A., Miura, A., ... Date, C. (2015). Estimation of habitual iodine intake in Japanese adults using $16 \mathrm{~d}$ diet records over four seasons with a newly developed food composition database for iodine. British Journal of Nutrition, 114(4), 624-634.

Lang, D., \& Scott, S. V. (2014). Australian Strategic Policy Institute Report Part Title: Background paper A rules-based order for the Asia-Pacific: identifying opportunities for Australia - Japan cooperation Report Part Author ( $s$ ): Shirley V Scott Report Title : Strengthening rules-.

Nugrahani, F., \& Al-Ma'ruf, A. I. (2015). Metode Penulisan Karya Ilmiah. Yogyakarta: Nuansa Aksara.

Panagiotopoulos, M. (2016). Australia and Japan create a new economic paradigm. Australia-Japan Foundation Project 2015, 16.

Rahayu, S., \& Arianti, R. K. (2014). Persepsi National Branding Sebagai Upaya Meningkatkan Kinerja Ekspor Ke Jepang dan Australia. Buletin Ilmiah Litbang Perdagangan, 8(2).

Satake, T. (2015). Why a Strong Australia-Japan Relationship Matters? Australia and Japan in the Region, Forum of the Australia-Japan Research Centre, 3(5).

Seran, M. (2014). Perlindungan Hukum Bagi Pasar Tradisional di Era Globalisasi Dan Liberalisasi Perdagangan. Masalah-Masalah Hukum, 43(3), 389-395.

Wijayanti, Y. (2019). Dinamika Hubungan Bilateral Indonesia-Australia. Jurnal Artefak, VII(09), 6.

WILKINS, M. C. and T. (2020). The Quiet Achiever: Australia-Japan Security Relations. (2011).

Yadav, R. S. (2015). Geo-Political Construct of Indo-Pacific Region and IndiaAustralia Relations. Political Discourse, 1(2), 3-17.

Yusuf, A. M. (2016). Metode penelitian kuantitatif, kualitatif \& penelitian gabungan. Prenada Media. 